\title{
東北海區カッ⿻魚体組成について ※
}

\section{山 中 一 郎 (日本海区水研究所)}

§1. 東北海区に於けるカツオの魚體测定の結果については、さきに昭和14年及15年仙本五郎三氏 (1) (2)が氣仙沼に於て行つたもの、昭和18年農林省水桽試驗場委託漁船によるるの。昭和22年及び23年に 著者主として石卷及び氣仙沼にて测定せるものに、若千の委呢船によるものを加えたものがあるがが、 てれ等を用いてカツォ魚體季節的変化及ての數年間の変化について考察を行つて見た。

§ 2, 测定したものは體長及び體重であるが昭和14１5年年のものにつんては原資料がないので體重組

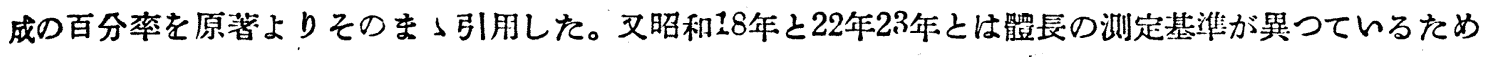

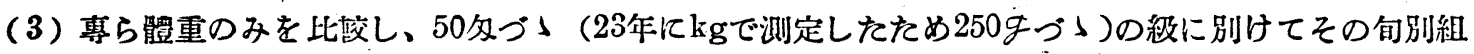
成を第一困に示した。侗測定せる個體總數は18年2529尾、22年1856尾、23年3608尾である。次に各年の 魚體総成の季節的変化を概述する。

\section{昭和14年}

（1）A群 (4) 6 月下旬 550 多に一つQモードがあり、順头体重を增加して9月に $700-750$ 多となつて絡漁とな ろ。

（2）B群 7 月下旬 750 多をモードと寸方群で 10 月下旬 950 多となる。

(3) C 群 8 月下旬頃より現はれ $200-3000$ 多の小型である。

(4) D群 9 月上旬 450 多にモードが現はれ終りに 500 名位となる。

\section{昭和15年}

（1）、 6 月に5 50 多、8月中旬に 800 多となつている。併しモードの位置は前年よりす大である。

(2) B 群 前年よりる現はれ方が早く、6月中旬に見出されている。かつその混合率け大であつたが、8月に入つて不 明膫となつた。

（3）。群 D群いずれも8月下旬以後の記錄がないため不明である。

\section{照和18年}

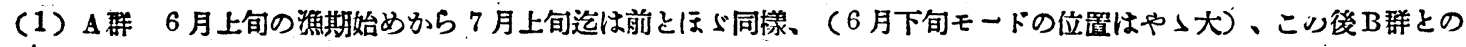
区別方㳅明膫となつた。

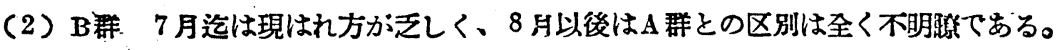

（3）Ｃ８月下旬より 250 欢の所に現はれ終海期には 300 双となつた。

（4） D群 C 群との区別はつけ難いが、1.4 年よりや小小さい。

\section{昭和22年}

（1）A 6 月下旬には昭和 18 年と同樣の所にモードがあるが、これがAに属するかどらかは不明である。その後の モードはAに近い時とBに近い時があるが、その区分は团難である。

(2) $\mathrm{O}$ 群 D前者は 8 月中旬、後者は 9 月下旬に現ばれるが、この二つの区別る亦団難である。

\section{昭和23年}

$\triangle \mathrm{B} の 2$ 群は全く別けられず、この 2 群の中間に相当する所にモードがある。又心は 8 月上旬にDは終漁期に僅か見られ ろのみである。

$!$ 一方昭和18年以後のものについて全漁期合計のものを見ると（第 2 因）、昭和18年には400、800、及び10

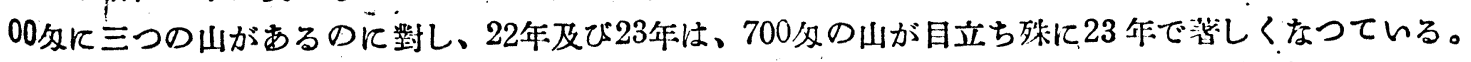
§3, 以上の結果沉ついて考察を行つて見る。昭和14年にはA群が B群に對して非常に多的のである が、近年 Bの混合率が增して(文はAが咸じて)、ての二つの区別が不明瞙となつだのではないかと考え

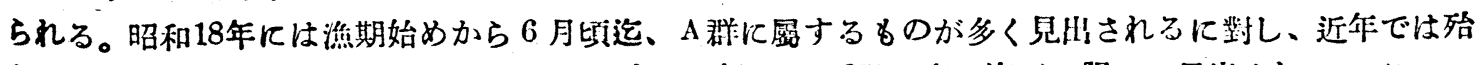

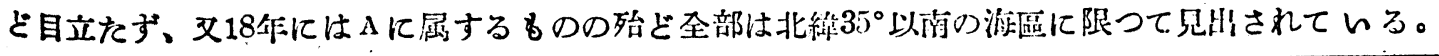

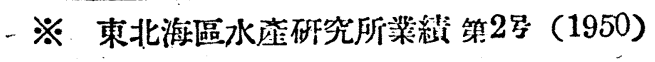



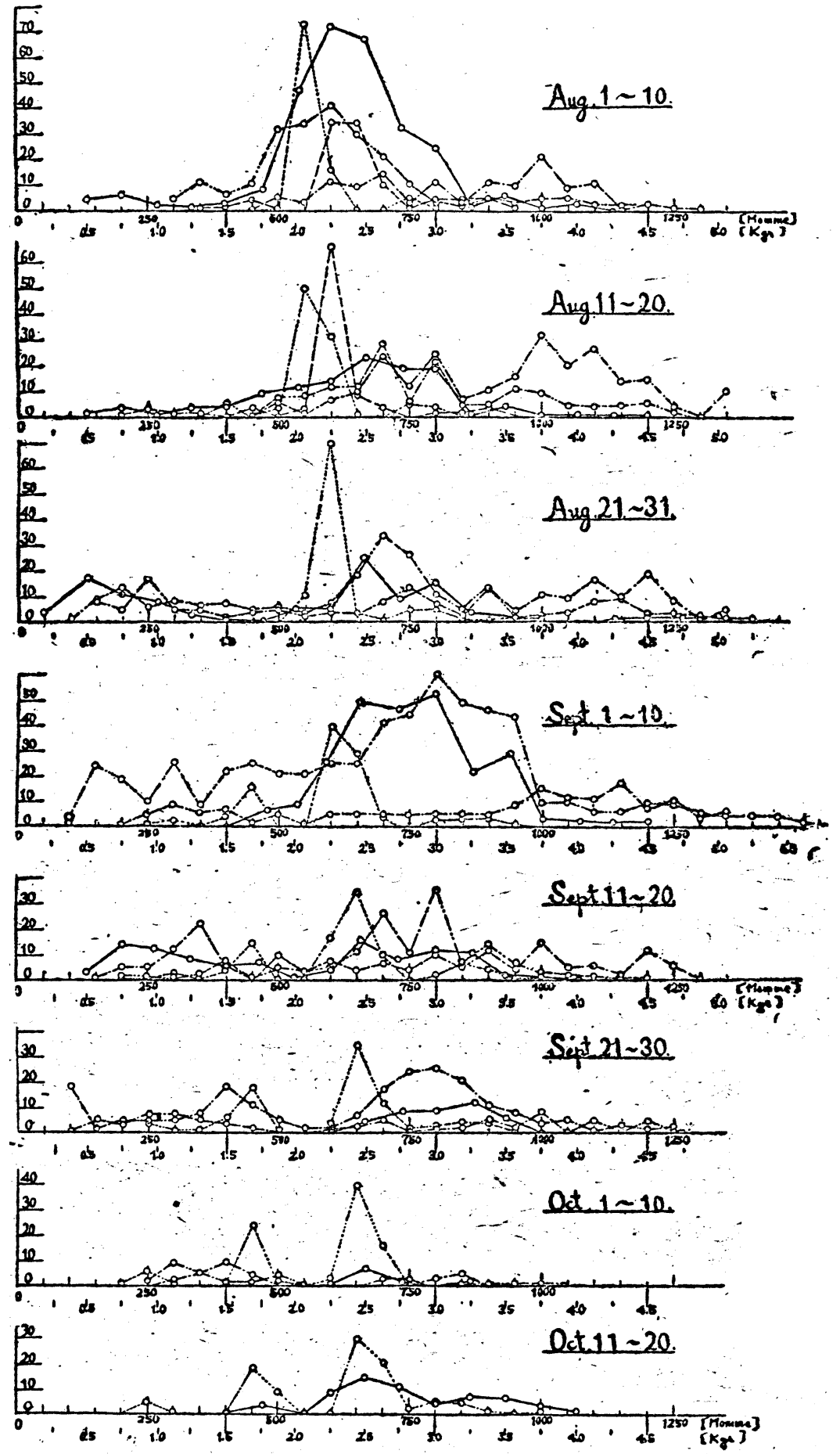

Fig. I. Seasonal Change of Body-uright Compocition

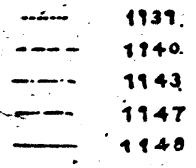



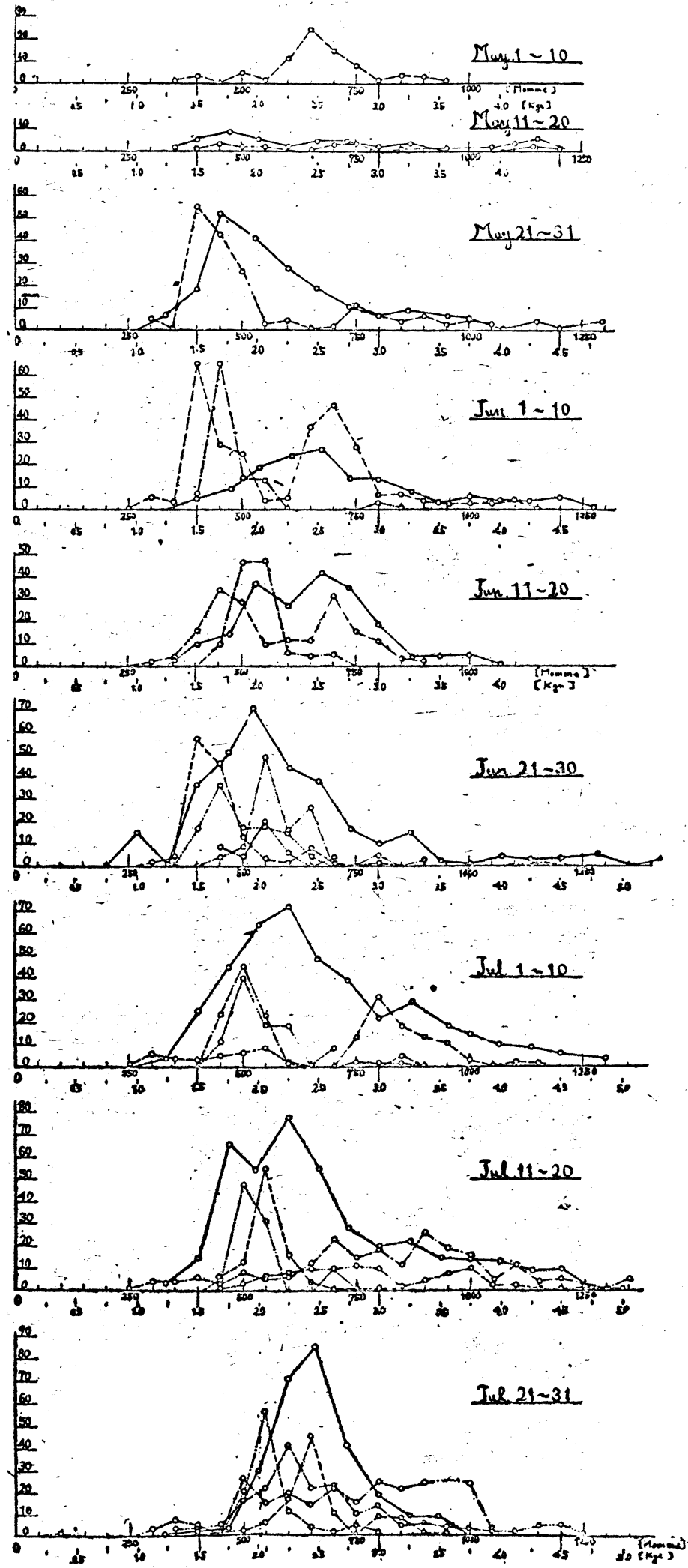


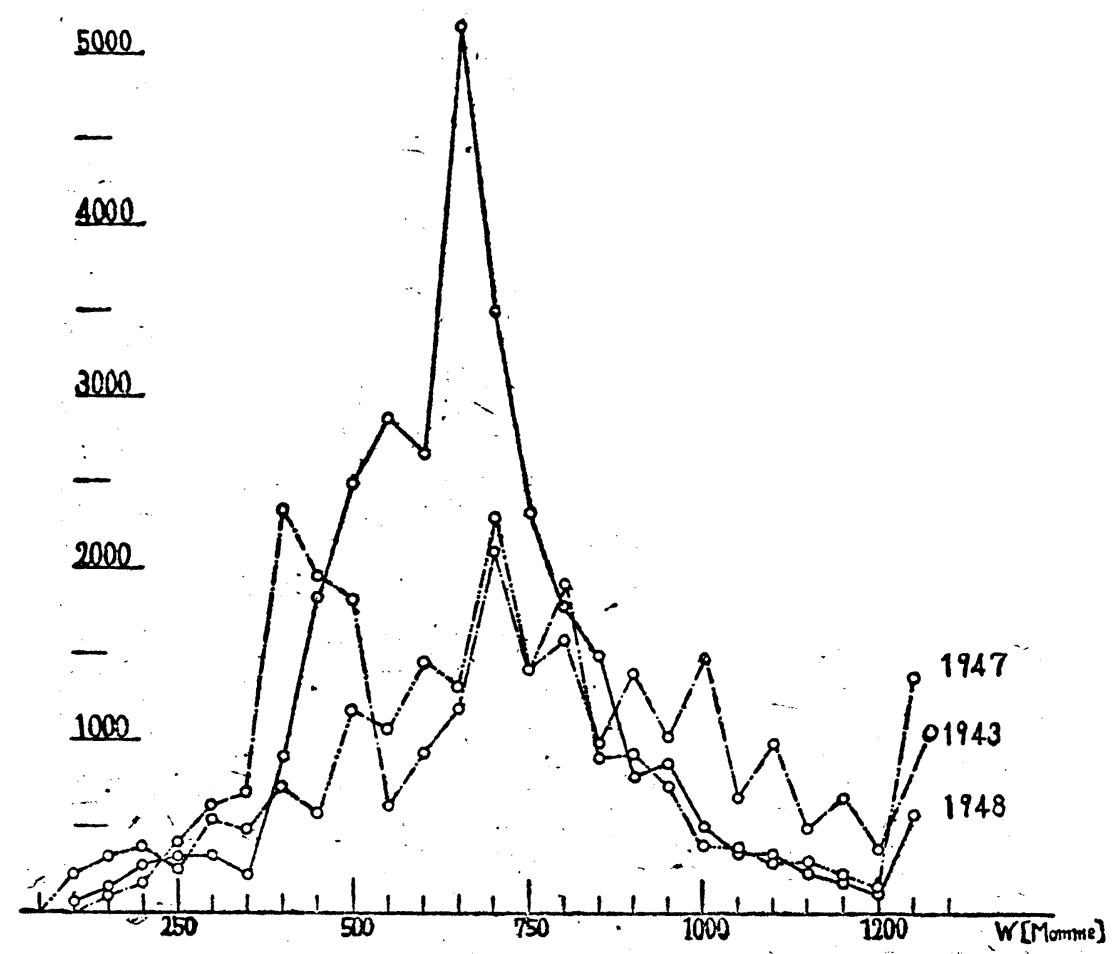

Frig II. Bodg-weight Compiosition Throgh totalyear 1443,-47,48 （弗3凶）そしてての兩者の混つたのるは僅かである。

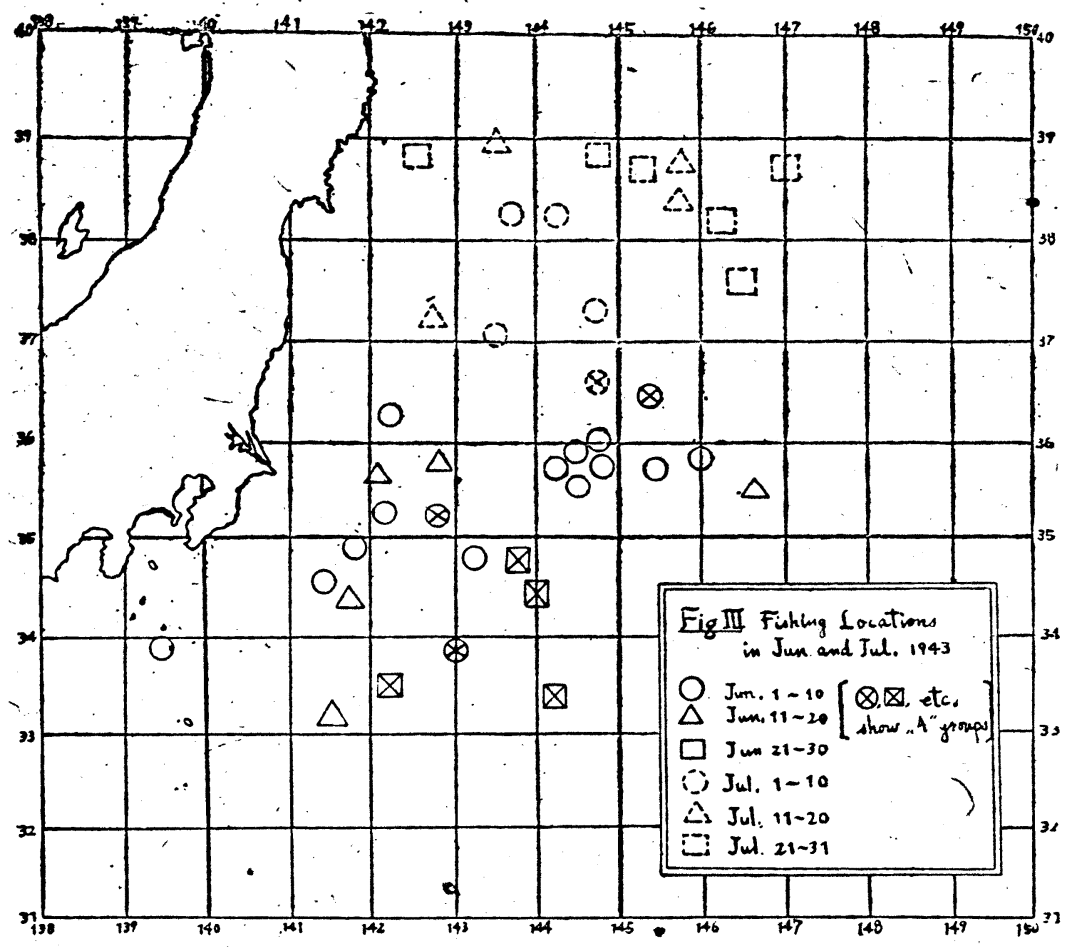




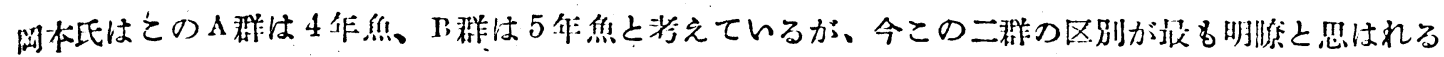

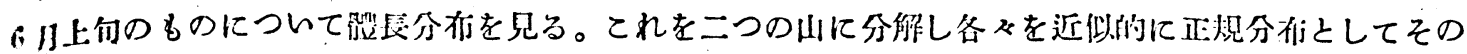

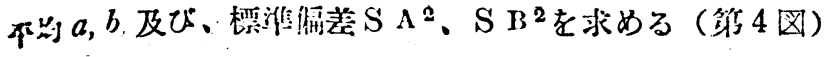

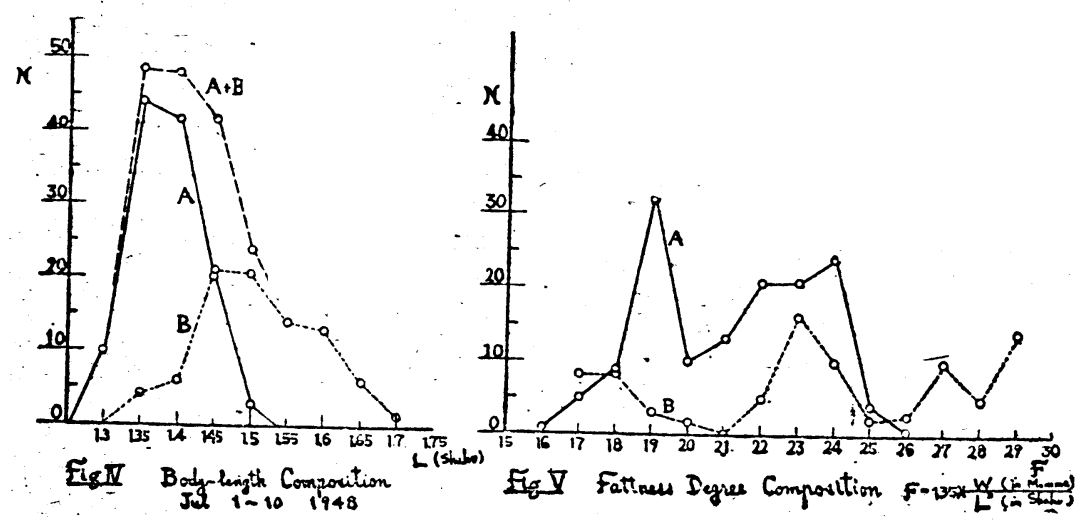

A 群 (116尾) $a=1.38$ 尺 $\quad \mathrm{S} \mathrm{A}^{2}=0.0036$

B群 ( 80 尾) $b=1.50$ 尺 $\quad \mathrm{S} \mathrm{B}^{2}=0.0118$

$$
a \sim b>3 \sqrt{\frac{\mathrm{SA}^{2}}{116}+\frac{\mathrm{SB}^{2}}{80}}
$$

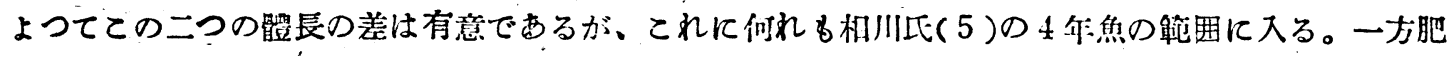

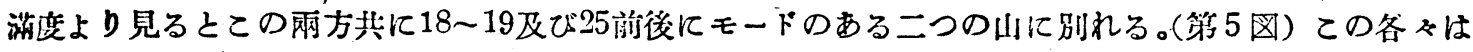

（6）相川氏の瀨付性群及び迥遊性胼と見なしてもよいが、同時て得られた一资料についてもこの二つ の山が得られるので、この二つは同時に混つている事になる。(一方昭和23年の肥滿度测定に上れば

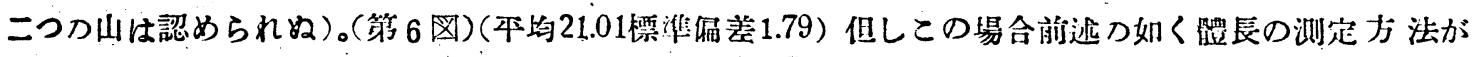

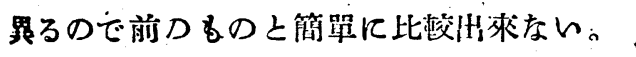

又同時季 (昭和 18 年 6 月) イナンバ、鳥島方面で得られ た瓷料について测定を行つをるのがあるが、これによる と䯏長は1.1尺〜2 尺まで出現し、肥滿度は $35 \sim 52$ とい5

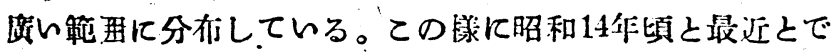
はカツオの魚體縕成に变化が認められるが、ての差異が何 を意味するかは檢討を要する問題であろう。

終りと本稿の作成江指蛍を與えられた木村喜之助理博及

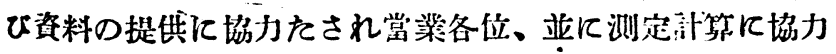

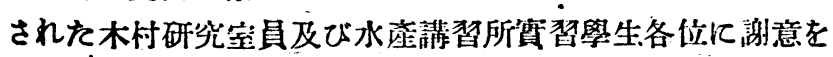
考する。

\section{突 考}

(1) (2) 岡本五郎三日水誌 9 (1940)PP, 100 海洋図年報 昭 15 (1940)

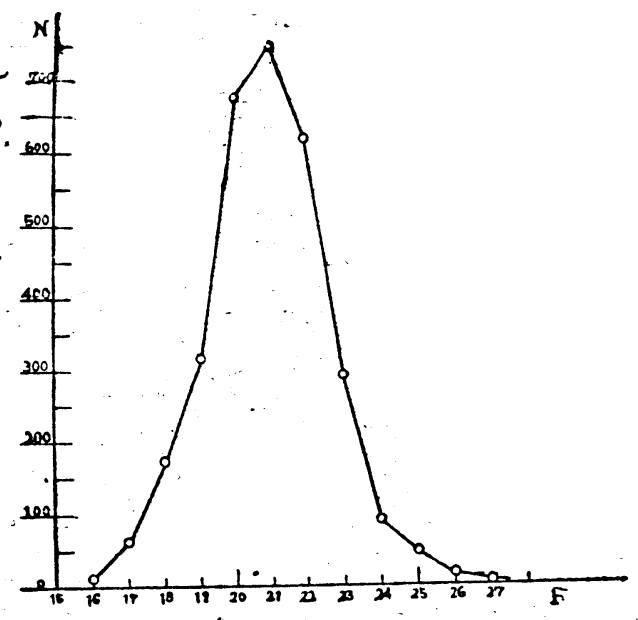

Eig VII Fattreu Degree Composition S1948I.

(3)测定基淮は右の图通り

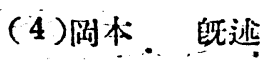

$(5)(6)$ 相川废秋 日水誌㖕6 (1937) PP,12 


\section{On Borly-Measurment of \\ Bonito [Katswonus vagans (Lesson)] \\ North-Eastern Area}

\section{Ichiro. Yamanalia}

\section{(Synopsis)}

Comparing the results of body-measurment of bonito canght in North-Fastern Area in 1930, 40, and 43 with those in 1947 and 48 , in the former a remarlable distinction is found between two different groups, but it became obscure in the case of the latter. This can be considered as caused by the change of migaration condition. 